\title{
СТРАТЕШКИ ПРИСТУП ЕВАЛУАЦИЈЕ ВРЕДНОСТИ КОДЕКСА ЧАСТИ ПРИПАДНИКА ВОЈСКЕ СРБИЈЕ
}

\author{
др Срећко Кузмановић ${ }^{1}$
}

\begin{abstract}
Апстракт
Кодексом части припадника Војске Србије уређују се општа морална начела војне професије, њене основне вредности и норме понашања припадника Војске Србије, који своје понашање усклађује и са одредбама Кодекса части. Истраживање смо започели претпоставком да су вредности предвиђене Кодексом части правилно одређене, узимајући у обзир да су оне водиља наших животних одлука. Истраживање смо реализовали на репрезентативном узорку од 1.477 испитаника, професионалних припадника Војске Србије, применом скале процене Ликертовог типа аутора текста “СВ-2011“, која обухвата 63 вредности. Од испитаника је тражено да процене колико су за њих важне понуђене вредности и да на листу за одговоре заокруже број који описује одговор са којим се слажу. Применом факторске анализе дошли смо до закључка да су се кардиналне војне вредности издвојиле као најважнији фактор, који у себи садржи девет од десет вредности предвиђених Кодексом части. На тај начин смо извршили евалуацију датих вредности и дошли до сазнања да су исте правилно одређене од стране радног тима за израду Кодекса части. Резултати истраживања нас не могу са сигурношћу довести до закључка да је дошло до прихватања наведених вредности, и то зато што је временски период од момента усвајања Кодекса части до реализације истраживања кратак.
\end{abstract}

Кључне речи: вредности, кодекс части, кардиналне војне вредности, факторска анализа

\section{КОДЕКС ЧАСТИ ПРИПАДНИКА ВОЈСКЕ СРБИЈЕ}

Професионални морал представља систем моралних обавеза друштвених или професионалних група, скуп правила, прописа, смерница, норми и идеала, које су чланови професије дужни да следе, а писано или неписано се излаже у кодексу части (етичком кодексу професије). Кодекс части обезбеђује прописе за морално значајну ситуацију у одређеној социјалној заједници и мора да буде потпун и

\footnotetext{
${ }^{1}$ Војна академија, Универзитет одбране у Београду, Е-пошта: srecko.kuzmanovic@gmail.com
} 
доследан. Пошто кодекс части представља етички кодекс професије, потребно је да појаснимо част и професију, односно професионализам.

Част представља ону моралну заповест која нас покреће да у свакој прилици човечност у себи, достојанствено и неокаљано сачувамо. Част је спољашњи израз човековог достојанства и исконски данак ${ }^{2}$ (поштовање и признање) који човеку указују његови другови и суграђани. Што је већа и узвишенија дужност коју професионални припадник Војске Србије испуњава, утолико је већа част која му се и одаје. Што је несебичнији и оданији у испуњавању својих дужности, толико је већа и његова лична част. Највећа част сваког професионалног припадника је заслужити поштовање и признање својих претпостављених, потчињених и суграђана. Од њега се очекује да је частан - да се држи моралне заповести којом чува унутрашњу част, односно човечност у себи, али и да је частољубив - да је прожет љубављу за спољном чашћу, за свим што је добро и племенито. Част га чини издржљивим, несебичним, постојаним, смелим, чврстим и сигурним у свим ситуацијама и представља његову светиљку и компас која му указује прави пут током његових искушења. Д. Маринковић сматра да је част „скуп свих вредности које човек има и ужива као људско биће и као члан људске заједнице ... уколико се више испуњавају моралне дужности, утолико расте или опада његова морална вредност“.3

Професија обезбеђује друштву часна (неупоредива) добра, којим се тежи због њих самих, док остали послови обезбеђују инструментална (упоредива) добра. Тако медицинска професија друштву обезбеђује часно добро - здравље, правна професија обезбеђује правду, просвета - образовање, новинарство - истину, свештенство - спасење, рачуноводство - поверење, док официрска професија обезбеђује часно (неупоредиво) добро - безбедност. Дакле, професионалац пружа услуге неопходне за функционисање друштва, попут здравља, образовања, правде, истине, спасења, поверење или безбедности, док су његови критеријуми стручност, одговорност и припадност групи. Професија захтева високо образовање, заснива се на наукама, има монопол у одређеној друштвеној делатности, свој језик (жаргон), своја удружења и свој професионални морал.

Кодексом части припадника Војске Србије 4 уређују се општа морална начела војне професије, њене основне вредности и норме понашања припадника Војске Србије.

2 Некада је данак представљао исказивање поштовања или признања према некоме, а касније је представљао материјалну обавезу коју је неки град или држава морала испунити у корист другог града или државе. Данак се везује и за вазални однос, односно финансијску обавезе вазала према неком великом царству. У савременом свету се данак преселио у подручје криминала и заменио термином „рекет“.

3 Маринковић, Д.; О заштити официрске војничке части, Свеславенска књижара Стефановић, Београд 1932, 10.

4 Радни тим формиран у Управи за људске ресурсе (J-1) ГШ ВС од представника организационих делова Министарства одбране и Генералштаба Војске Србије стручних лица из области етике, историје, социологије, права и психологије, израдио је Кодекс части припадника Војске Србије. Тим су сачињавали Стевица С. Карапанџин, пуковник др Илија Кајтез, пуковник др Борислав Д. Гроздић, капетан мр Далибор Денда, капетан мр Миљан Милкић, поручник Дејан Андрић и поручник Вук Вујовић. Представници Филозофског факултета (проф. др Јован Бабић и доц. др Иван Вуковић), 
Кодекс части чува, негује и развија највредније српске војне традиције. Поред обавезе да поступа у складу са Уставом, законима, војним прописима и нормама међународног хуманитарног права, као и општим друштвеним и моралним начелима, вредностима и нормама, припадник Војске Србије своје понашање усклађује и са одредбама Кодекса части. Пуковник Стевица Карапанџин, генералштабни официр који је био један од носиоца израде моралног кодекса наше војске, истиче: „Савремена војна пракса сведочи о оправданости кодификације понашања припадника војне професије, чему у прилог иде и чињеница да се стручним војним правилима тешко може прописати њихова етичност, како у свакодневним мирнодопским условима, тако и приликом извођења операција. Убрзана и свеобухватна реформа система одбране Републике Србије и реорганизација Војске Србије, уз очекивање њене професионализације и нових мисија, представљају нов амбијент у коме се јавила потреба доношења посебног документа, као реалног оквира за уређење области чија суштина није обухваћена законском и подзаконском регулативом. Многа етичка питања са којима су се у нашој досадашњој војној пракси сусретали припадници војне професије, како у служби, тако и ван ње, била су искључиво у сфери обичајног, али не и нормативног“.5 Уважавање општих моралних начела војне професије, неговање и развијање њених основних вредности и достизање дефинисаних норми понашања у личној је одговорности припадника Војске Србије. Припадник Војске Србије руководи се следећим општим моралним начелима: служење отаџбини Србији; савесно и стручно вршење дужности; човечно поступање.

Припадник Војске Србије промовише основне вредности предвиђене Кодексом части тако што негује и развија сопствене врлине и прихвата и поштује норме понашања: са отаџбином је у заветном односу и безусловно је брани; поштује, чува и брани државна и војна обележја и достојанствено носи униформу Војске Србије, у служби и ван ње; приликом извршавања борбених задатака силу употребљава само колико је неопходно, и човечно поступа према заробљеном непријатељу и цивилима, посебно према старијим особама, женама и деци; не дозвољава да средства ратне технике која су му поверена доспеју исправна у посед непријатеља, а у случају заробљавања, одбија сарадњу која је у супротности са правним нормама и одредбама Кодекса части; не прихвата чин издаје; никада другог припадника Војске Србије не оставља у невољи; поштује личност и различитости; не псује, не вређа и не изражава се погрдно о вредностима које другима представљају светињу; посвећен је војној професији и живи у складу са њеним вредностима; настоји да контролише понашање, буде смирен и прибран, а

Српске академије наука и уметности (Данило Баста), Института за модерну историју Србије (др Александар Животић), Института за савремену историју (др Бојан Б. Димитријевић) и Министарства вера Републике Србије (мр Александар Раковић). У раду је учествовала и Гордана Стевановић из Заштитника грађана Републике Србије, у своје лично име, не као представник наведене институције.

5 Карапанцин, С.; Кодекс части припадника Војске Србије, Нови гласник, Београд 2012, стр. 125. 
у борби са собом, непријатељем и природним стихијама непоколебљив, држи дату реч, буде самокритичан, правдољубив, истинољубив, трпељив, скроман, поуздан и отворен, личне интересе усклађује са општим, не буде порочан, сујетан, осветољубив, осоран, бахат, хвалисав и охол, не ласка и не оговара друге, буде морални узор за све чланове друштва.

Повреда Кодекса части од стране припадника Војске Србије повлачи моралну одговорност и сматра се недостојним поступком, који другим припадницима Војске Србије представља негативан пример у понашању. Кодекс части је саставни део планова и програма свих нивоа оспособљавања, школовања и усавршавања у Војсци Србије. Унапређење општег нивоа поштовања одредаба Кодекса части постиже се командовањем, обуком, контролом и свакодневним васпитним радом претпостављених.

За припадника Војске Србије, основне вредности предвиђене Кодексом части су: верност отаџбини (припадник Војске Србије је веран отаџбини Србији, он ту верност сматра војничким идеалом); посвећеност професији (стручно и одговорно обавља своје послове, он служи у свим мисијама Војске Србије без обзира на тешкоће и опасности); оданост (привржен је својој јединици, он помаже другом припаднику Војске Србије у свим околностима); храброст (спреман је да се суочи са неизвесношћу, опасностима и злом, он тада доноси исправну и разумну одлуку без обзира на ризик); дисциплинованост (поштује Устав, законе и војне прописе, он свесно и савесно испуњава своје обавезе и извршава наређења претпостављеног); солидарност (са другим припадницима јединице дели проблеме професије, он својим понашањем доприноси развоју међусобног поверења и заједништва); човечност (не злоставља, не вређа и не понижава друге, он не користи силу већу од оне која је неопходна да би се непријатељ савладао); достојанство (чува целовитост своје личности и личности другог, он настоји да унапреди углед и поверење које припадници Војске Србије имају код грађана); пожртвованост (спреман је на одрицања ради добробити отаџбине, Војске Србије и своје јединице, он за то не очекује награду) и поштовање (своју част и част другог сматра једнаким, он не повређује вредности и светиње другог и не чини другом оно што не жели да чине њему). Наведене вредности представљају највише циљеве који се остварују врлинама и понашањем припадника Војске Србије.

\section{КОДЕКС ЧАСТИ ДРУГИХ ПРОФЕСИЈА И СТРАНИХ ОРУЖАНИХ СНАГА}

Лекарски кодекса части: лекар и стоматолог (у даљем тексту лекар) свечано се обавезују да ће свој позив обављати савесно и одговорно и да ће поштујући традиције професије применити своје познавање вештине лечења на најхуманији начин; унапређивање и чување здравља, лечење оболелих и продужење људског века је основни задатак сваког лекара; лекар увек пружа свима подједнако стручну помоћ, без обзира на расу, веру, пол, националност, политичку припадност и социјални положај; поступајући по правилима науке и струке, лекар је дужан да примени савремену медицинску доктрину; лекар је дужан да чува 
углед и достојанство професије и не сме ни под претњом употребити своје знање насупрот професионалним правилима и закону; према својим учитељима и колегама ће исказивати дужно поштовање; и чуваће тајну која му је поверена.

Новинарски кодекс части: дужност поштовања истине, заштите људских права и објективног информисања јавности; дужност провере тачности информација, те забрана њиховог искривљивања и фалсификовања; објављивање лажних вести повлачи дужност њиховог кориговања на примерен начин; дужност је да се вести, информације и подаци прибављају на частан начин; дужност новинара да штити углед професије и штити пословну тајну; дужност је да избегава утицај приватних или пословних интереса трећих лица; и дужност је да уважава приватни живот људи, искључујући његову повезаност с јавним интересом.

Судијски кодекс части налаже да њихови професионални припадници морају да буду независни, праведни, слободни, храбри, долични, неподмитљиви, посвећени, професионални, аполитични и одани кодексу части.

Полицијски кодекс части: морална дужност полицајца да служи човечанству, да чува животе и имовину, да штити невине, да штити од насиља и угњетавања и да поштује слободу, права и једнакост свих људи; морална дужност личног понашања полицајца (вођење часног приватног живота, дужност уздржавања у случају опасности, презира и исмевања, дужност искрености, дужност чувања службене тајне итд.); дужност самоконтроле пред властитим предрасудама, осећањима, анимозитетима и пријатељствима; и дужност оданости према службеној дужности поштовања властите професије и закона.

Кључне вредности у британској војсци су: несебична посвећеност, храброст, дисциплинованост, интегритет, лојалност и поштовање према другима. У војсци САД-а су заступљене следеће вредности: лојалност, дужност, поштовање, несебична посвећеност служби, част, интегритет и лична храброст. Руски официр се руководи слоганом душа Богу, живот отаџбини, а част никоме. У немачкој и аустралијској војсци су заступљене следеће вредности: професионализам, лојалност, иновације, храброст, интегритет и тимски рад. Основне вредности у канадској војсци су: искреност, лојалност, интегритет, храброст, правичност и одговорност.

„Кадет неће лагати, варати, или красти, или толерисати оне који то буду радили“. Ове речи обезбеђују темељ на којем почива морал и етика кадета на Вест Поинту, који су одговорни за развој и примену њиховог Кодекса части. Овај Кодекс части обезбеђује примену професионалних стандарда понашања и самоконтроле кадета Вест Поинта. На овај начин се истиче и њихова нетолеранција према негативним појавама лагања, варања и крађе. Ове забране представљају минималне стандарде етичког понашања по којима кадети морају да живе и они не представљају апстрактне идеале којима треба тежити и пуке забране, већ начин њиховог живота. Дух Кодекса части обележава карактер правих лидера и поставља стандарде осталим старешинама. Кодекс представља скуп општих фундаменталних принципа којима се изражава интегритет и врлине самог човека и манифестује се у његовим делима. 


\section{ИСТРАЖИВАЊЕ ПОСТОЈЕКЕГ СИСТЕМА ВРЕДНОСТИ}

Израз „вредност“ потиче од латинског термина „valeo“, који значи крепак, јак, здрав. У српском језику реч „вредност“ има широку употребу и значи врлину, доброту, снагу, моћ, храброст, али и цену и корисност. Ђуро Шушњић с пуним правом тврди да вредности одређују смисао живота свакога од нас, то су стварни или идеални предмети за које се вежу човекове потребе и жеље и то да човек види свет оним очима у зависности од тога које су му изабране вредности. ${ }^{6}$

До постојећег система вредности професионалних војних лица Војске Србије покушали смо да дођемо поступком дескриптивне статистике, факторском анализом, униваријантном анализом варијансе и Данкановим тестом опсега. Први део података истраживања о постојећем систему вредности професионалних војних лица Војске Србије добијен је помоћу петостепене Скале процене „СВ-2011“ аутора текста (Табела 1) Ликертовог типа, која обухвата 63 различите вредности. Испитивање је обављено на репрезентативном узорку од 1.477 испитаника (6,91\%) - професионалних војних лица Војске Србије и то 271 официра (6,23\%), 399 подофицира (5,78\%) и 807 професионалних војника (7,96\%), свих видова, родова и највећег дела служби. Од испитаника је тражено да процене колико су за њих важне понуђене вредности и да на листу за одговоре заокруже број који описује одговор са којим се слажу. Скала процене „СВ-2011“ обухвата распон од: веома важно (5), важно (4), средње важно (3), мало важно (2) и неважно (1). Понуђене вредности су изабране на основу вредности које се истичу у Уставу Републике Србије, Стратегији националне безбедности, Кодексу части припадника Војске Србије, као и прокламованим европским вредностима. У наведеној скали процене свака вредност је укратко описана, чиме је у многоме пренебрегнута могућност да испитаници различито тумаче поједине вредности.

Како би се донекле превазишао проблем истинитог одговарања на постављена питања, анкете су анонимно попуњаване, а истраживач је присуствовао анкетирању са сваком групом испитаника. Пре почетка активности испитаницима је објашњено да ће се резултати истраживања користити искључиво у научне сврхе, да се не разматрају појединачни резултати већ на нивоу целе групе и да је изузетно важно исказивање искрених ставова.

Добијени подаци истраживања су приказани у Табели 1 и представљају средњу вредност, стандардну девијацију и ранг ставова испитаника према понуђеним вредностима.

6 Шушњић Ђ.; Религија I, Чигоја, Београд 1998, 215-222.

7 Величина одступања од средње вредности на основу које процењујемо хомогеност испитаника. Група је хомогенија што је стандардна девијација мања, и обрнуто. 
Табела1: Основни статистички показатељи вредности ${ }^{8}$

\begin{tabular}{|c|c|c|c|c|}
\hline Ранг & НАЗИВ ВРЕДНОСТИ & $\begin{array}{c}\text { Средња } \\
\text { вредност }\end{array}$ & Ст. Дев. & $\begin{array}{l}\text { Ред. бр. } \\
\text { вредности } \\
\text { у упитнику }\end{array}$ \\
\hline 1 & $\begin{array}{l}\text { ПОРОДИЦА (људска заједница усмерена ка } \\
\text { подизању потомства, задовољавању емотивних и } \\
\text { биолошких потреба и обезбеђивању } \\
\text { материјалних услова за живот) }\end{array}$ & 4,9025 & ,34133 & 52 \\
\hline 2 & $\begin{array}{l}\text { ЗДРАВЉЕ (представља одсуство болести које за } \\
\text { последицу има психофизичко, духовно и } \\
\text { друштвено благостање) }\end{array}$ & 4,8565 & ,45649 & 56 \\
\hline 3 & $\begin{array}{l}\text { СЛОБОДА (супротно од спутаности, када човек } \\
\text { може да делује без присиле, принуде и забране) }\end{array}$ & 4,7102 &, 55214 & 5 \\
\hline 4 & ПОШТЕЊЕ (честитост) & 4,6899 &, 59354 & 9 \\
\hline 5 & $\begin{array}{l}\text { МИР (одсуство рата, идеално стање друштва у } \\
\text { коме влада лично и друштвено благостање) }\end{array}$ & 4,6188 & ,66687 & 18 \\
\hline 6 & САВЕСНОСТ (одговорност) & 4,6154 & ,54696 & 3 \\
\hline 7 & $\begin{array}{l}\text { ПРИЈАТЕЉСТВО (позитиван однос између људи } \\
\text { који осећају међусобну симпатију и поверење) }\end{array}$ & 4,6039 & ,59086 & 13 \\
\hline 8 & $\begin{array}{l}\text { ДОСТОЈАНСТВО (настојање да се унапреди } \\
\text { сопствени углед, као и углед и поверење } \\
\text { припадника ВС у друштву) }\end{array}$ & 4,5592 & ,59814 & 1 \\
\hline 9 & ЈЕДНАКОСТ (сви људи су једнаки пред законом) & 4,5498 & ,75511 & 58 \\
\hline 10 & $\begin{array}{l}\text { ПОШТОВАҢЕ (када човек своју и част другог } \\
\text { сматра једнаком и када не повређује личност } \\
\text { другог) }\end{array}$ & 4,5477 & ,59690 & 54 \\
\hline 11 & ЧВРСТИНА КАРАКТЕРА (постојаност личности) & 4,5261 & ,61389 & 16 \\
\hline 12 & $\begin{array}{l}\text { БЕЗБЕДНОСТ РЕПУБЛИКЕ СРБИЈЕ (одсуство } \\
\text { физичког и духовног угрожавања основних } \\
\text { вредности грађана Републике Србије и њихових } \\
\text { добара) }\end{array}$ & 4,5146 & ,68912 & 53 \\
\hline 13 & $\begin{array}{l}\text { ОБУЧЕНОСТ (стечена знања, вештине и } \\
\text { способности неопходне за обављање } \\
\text { функционалних дужности у својој јединици - } \\
\text { установи) }\end{array}$ & 4,4827 & ,66198 & 28 \\
\hline 14 & МУДРОСТ (добро расуђивање) & 4,4692 & ,63643 & 23 \\
\hline 15 & $\begin{array}{l}\text { ЧОВЕЧНОСТ (представља хуманост и настојање } \\
\text { да се свом ближњем помогне односно супротност } \\
\text { од вређања понижавања и злостављања других) }\end{array}$ & 4,4651 & ,65821 & 51 \\
\hline 16 & $\begin{array}{l}\text { ОЧУВАҢЕ ПРИРОДЕ И ЧОВЕКОВЕ ОКОЛИНЕ } \\
\text { (настојање да се реше бројни проблеми који } \\
\text { угрожавају човекову околину и опстанак } \\
\text { природе) }\end{array}$ & 4,4489 & ,72946 & 62 \\
\hline 17 & $\begin{array}{l}\text { 3НАњЕ (настојање да се сталним процесом учења } \\
\text { прошире личне границе познатог) }\end{array}$ & 4,4414 & ,63555 & 35 \\
\hline 18 & $\begin{array}{l}\text { ПОСВЕЋЕНОСТ ПРОФЕСИЈИ (стручно, савесно и } \\
\text { одговорно обављање својих послова и задатака) }\end{array}$ & 4,4333 & ,64112 & 6 \\
\hline 19 & $\begin{array}{l}\text { НЕЗАВИСНОСТ (када грађани без спољних } \\
\text { утицаја управљају државом преко својих } \\
\text { представника) }\end{array}$ & 4,4292 & ,74620 & 55 \\
\hline
\end{tabular}

8 Табеле су резултат ауторове обраде података резултата истраживања, коришћењем програма SPSS 14.0. 


\begin{tabular}{|c|c|c|c|c|}
\hline Ранг & НАЗИВ ВРЕДНОСТИ & $\begin{array}{c}\text { Средња } \\
\text { вредност }\end{array}$ & Ст. Дев. & $\begin{array}{r}\text { Ред. бр. } \\
\text { вредности } \\
\text { у упитнику }\end{array}$ \\
\hline 20 & ИСТИНОљУБИВОСТ (посвећеност истини) & 4,4144 & 68492 & 24 \\
\hline 21 & КОЛЕКТИВНИ ДУХ (дух заједништва) & 4,3886 & ,71232 & 11 \\
\hline 22 & $\begin{array}{l}\text { НЕПОВРЕДИВОСТ ВЛАСНИШТВА (ВЛасник } \\
\text { својине има неотуђиво право да користи и } \\
\text { остварује интерес над својом имовином) }\end{array}$ & 4,3825 & ,75208 & 61 \\
\hline 23 & $\begin{array}{l}\text { ПРАВДОљУБИВОСТ (када ценимо правду у } \\
\text { смислу правичног, исправног и моралног } \\
\text { поступања) }\end{array}$ & 4,3751 & ,69950 & 39 \\
\hline 24 & $\begin{array}{l}\text { ДИСЦИПЛИНОВАНОСТ (савесно извршавање } \\
\text { наређења претпостављеног и поштовање } \\
\text { прописа и закона) }\end{array}$ & 4,3737 & 69048 & 46 \\
\hline 25 & $\begin{array}{l}\text { ВЛАДАВИНА ПРАВА (постојање правног поретка } \\
\text { у земљи и међународним институцијама, а не } \\
\text { самовоља појединаца и утицајних друштвених } \\
\text { група) }\end{array}$ & 4,3690 & ,79629 & 63 \\
\hline 26 & $\begin{array}{l}\text { ДРУЖЕЉУБИВОСТ (када човек није повучен у } \\
\text { себе, већ воли да проводи време са другим } \\
\text { људима) }\end{array}$ & 4,3602 & ,70825 & 20 \\
\hline 27 & $\begin{array}{l}\text { ЧАСТ (умереност између немања осећања части и } \\
\text { славољубља) }\end{array}$ & 4,3595 & ,75264 & 25 \\
\hline 28 & $\begin{array}{l}\text { СОЦИЈАЛНА ПРАВДА (представља стање у коме } \\
\text { већина или сви чланови друштва имају иста } \\
\text { основна права, могућности, обавезе и социјалне } \\
\text { користи) }\end{array}$ & 4,3453 & ,76858 & 60 \\
\hline 29 & $\begin{array}{l}\text { ЉУБАВ (усмереност према бризи, милосрђу и } \\
\text { добру других) }\end{array}$ & 4,3385 & ,71413 & 43 \\
\hline 30 & $\begin{array}{l}\text { ХЛАДНОКРВНОСТ (присебност при извршавању } \\
\text { ризичних задатака) }\end{array}$ & 4,3290 & ,76424 & 19 \\
\hline 31 & $\begin{array}{l}\text { ОДЛУЧНОСТ (супротно од сталног } \\
\text { преиспитивања одлука) }\end{array}$ & 4,3169 & ,64377 & 2 \\
\hline 32 & $\begin{array}{l}\text { ОДАНОСТ (приврженост својој јединици и свим } \\
\text { њеним припадницима) }\end{array}$ & 4,3067 & 72698 & 36 \\
\hline 33 & $\begin{array}{l}\text { ЛИЧНИ УГЛЕД (какво мишљење имају други о } \\
\text { вама) }\end{array}$ & 4,2864 & 83205 & 17 \\
\hline 34 & $\begin{array}{l}\text { ХРАБРОСТ (спремност да се човек суочи са } \\
\text { страхом, неизвесношћу и опасношћу без обзира } \\
\text { на ризик) }\end{array}$ & 4,2857 & 73503 & 49 \\
\hline 35 & $\begin{array}{l}\text { ЉУДСКА ПРАВА (су заснована на урођеном } \\
\text { људском достојанству, а одређена Универзалном } \\
\text { декларацијом о људским правима УН-а и другим } \\
\text { правним актима) }\end{array}$ & 4,2634 & ,84446 & 31 \\
\hline 36 & $\begin{array}{l}\text { НАДА (уверење у позитиван исход догађаја и } \\
\text { разних околности у животу) }\end{array}$ & 4,2586 & 77791 & 32 \\
\hline 37 & $\begin{array}{l}\text { ВЕРНОСТ ОТАџБИНИ (љубав, брига за отаџбину и } \\
\text { спремност да се жртвујемо за њу) }\end{array}$ & 4,2532 & ,84315 & 38 \\
\hline 38 & $\begin{array}{l}\text { САМОПОШТОВАЮЕ (умереност између } \\
\text { самопотцењивања и хвалисавости - } \\
\text { разметљивости) }\end{array}$ & 4,2058 & 80540 & 30 \\
\hline 39 & $\begin{array}{l}\text { ТРАДИЦИЈА (скуп духовних и материјалних } \\
\text { знања, достигнућа и вредности које се одржавају } \\
\text { усменим преношењем и на којима почива } \\
\text { идентитет неке културе) }\end{array}$ & 4,1564 & 79330 & 47 \\
\hline 40 & $\begin{array}{l}\text { АМБИЦИОЗНОСТ (намера и настојање да се на } \\
\text { основу својих способности и уложеног труда } \\
\text { напредује у служби) }\end{array}$ & 4,1469 & ,85742 & 12 \\
\hline
\end{tabular}




\begin{tabular}{|c|c|c|c|c|}
\hline Ранг & НАЗИВ ВРЕДНОСТИ & $\begin{array}{l}\text { Средња } \\
\text { вредност }\end{array}$ & Ст. Дев. & $\begin{array}{c}\text { Ред. бр. } \\
\text { вредности } \\
\text { у упитнику }\end{array}$ \\
\hline 41 & СКРОМНОСТ (супротно од разметљивости) & 4,1293 & ,77052 & 7 \\
\hline 42 & $\begin{array}{l}\text { УМЕРЕНОСТ (проналажење мере између две } \\
\text { крајности) }\end{array}$ & 4,1212 & ,75138 & 44 \\
\hline 43 & $\begin{array}{l}\text { ТОЛЕРАНТНОСТ (попустљивост, спремност на } \\
\text { компромисе, иако се са туђим схватањима не } \\
\text { слажемо) }\end{array}$ & 4,1178 & ,78152 & 4 \\
\hline 44 & $\begin{array}{l}\text { СВЕСТРАНОСТ (подручје интересовања није само } \\
\text { уско усмерено на занимање или професију којом } \\
\text { се човек бави) }\end{array}$ & 4,1158 & ,77179 & 14 \\
\hline 45 & $\begin{array}{l}\text { ПОНОС (умереност између понизности и } \\
\text { надувености - охолости) }\end{array}$ & 4,1124 & ,89615 & 22 \\
\hline 46 & $\begin{array}{l}\text { НАЦИОНАЛНА РАВНОПРАВНОСТ (једнакост свих } \\
\text { нација) }\end{array}$ & 4,1077 & ,96268 & 59 \\
\hline 47 & $\begin{array}{l}\text { СОЛИДАРНОСТ (свест о потреби узајамне } \\
\text { одговорности и настојање да се лични интереси } \\
\text { подреде интересима своје јединице) }\end{array}$ & 4,0636 & ,77390 & 41 \\
\hline 48 & $\begin{array}{l}\text { СВЕТИ ПРЕЦИ (личности које је Црква } \\
\text { прогласила за свеце на основу њихових добрих } \\
\text { дела, страдања и/или побожног живота) }\end{array}$ & 4,0569 & ,99906 & 8 \\
\hline 49 & $\begin{array}{l}\text { МИЛОСРЂЕ (добровољан чин самилости - } \\
\text { опраштања) }\end{array}$ & 4,0467 & ,75966 & 45 \\
\hline 50 & $\begin{array}{l}\text { ЦРКВА (установљена заједница људи уједињених } \\
\text { вером у једнога Бога) }\end{array}$ & 4,0183 & 1,03806 & 27 \\
\hline 51 & $\begin{array}{l}\text { НОВАЦ (као материјална вредност али и уверење } \\
\text { да само поседовање новца доноси сигурност и } \\
\text { поштовање) }\end{array}$ & 3,9878 & ,98353 & 34 \\
\hline 52 & $\begin{array}{l}\text { БОГ (свезнајуће, свемоћно, свеприсутно, } \\
\text { натприродно, бестелесно биће, стваралац и } \\
\text { надзорник свемира као и оличење савршеног добра) }\end{array}$ & 3,9695 & 1,06992 & 37 \\
\hline 53 & $\begin{array}{l}\text { ПОЖРТВОВАНОСТ (спремност на одрицања ради } \\
\text { добробити своје јединице, ВС и отаџбине без } \\
\text { очекивања награде) }\end{array}$ & 3,9425 & ,95994 & 29 \\
\hline 54 & $\begin{array}{l}\text { ДАРЕЖЉИВОСТ (супротно среброљубљу, } \\
\text { умереност између шкртости и расипништва) }\end{array}$ & 3,9370 & ,79597 & 48 \\
\hline 55 & $\begin{array}{l}\text { СПАСЕЊЕ (чин којим Бог човека поново доводи у } \\
\text { стање заједништва са собом) }\end{array}$ & 3,8422 & 1,08895 & 15 \\
\hline 56 & $\begin{array}{l}\text { РАВНОПРАВНОСТ ПОЛОВА (једнакост мушкараца } \\
\text { и жена у друштвеном и политичком животу) }\end{array}$ & 3,8030 & 1,06422 & 57 \\
\hline 57 & ПОСЛУШНОСТ (покорност, кротост) & 3,7549 & ,94542 & 40 \\
\hline 58 & $\begin{array}{l}\text { ДЕМОКРАТИЈА (политички систем базиран на } \\
\text { могућности грађана да бирају своје политичке } \\
\text { представнике) }\end{array}$ & 3,5308 & 1,18649 & 50 \\
\hline 59 & $\begin{array}{l}\text { ХЕДОНИЗАМ (Усмереност ка задовољству и } \\
\text { уживању) }\end{array}$ & 3,3893 & 1,09975 & 21 \\
\hline 60 & $\begin{array}{l}\text { МИСИОНАРСТВО (настојање да се сопствене } \\
\text { вредности пренесу другим људима изван } \\
\text { граница наше земље) }\end{array}$ & 3,2905 & 1,11724 & 26 \\
\hline 61 & $\begin{array}{l}\text { АВАНТУРИЗАМ (љубав према пустоловинама и } \\
\text { склоност излагању опасностима) }\end{array}$ & 3,2451 & 1,14447 & 33 \\
\hline 62 & $\begin{array}{l}\text { МОЋ (могућност да се својим положајем, } \\
\text { способностима и/или економском снагом } \\
\text { наметне воља другоме) }\end{array}$ & 3,0142 & 1,26841 & 10 \\
\hline 63 & $\begin{array}{l}\text { ПОПУЛАРНОСТ (настојање да будемо у центру } \\
\text { пажње непосредног окружења или јавности) }\end{array}$ & 2,9425 & 1,08766 & 42 \\
\hline
\end{tabular}


Резултати истраживања показују да су професионална војна лица Војске Србије спремна да поднесу највеће жртве за наведене вредности, зато што у њих човек верује, за њих живи и за њих је спреман да поднесе највеће жртве. Овако висок ранг првих десет манифестних варијабли, чија средња вредност прелази 4,50 нам говори да су то управо оне вредности које су високо рангиране у вредносној оријентацији испитаника, при чему су највећим делом веома важне за испитанике и њихов живот уопште. Ниска стандардна девијација (испод 0,75 ) нам говори о уједначености и хомогености групе при исказивању својих ставова о поменутом питању.

Један од задатака научног истраживања јесте утврђивање повезаности појава, чиме се омогућава предвиђање догађаја и појава које ће се збити на основу неких познатих индикатора или података. Поступак факторске анализе примењен је на целокупном узорку од 1.477 испитаника. Тиме су се, према унапред задатим математичкологичким условима, 63 различите манифестне варијабле редуковале на 12 базичних (латентних), које смо назвали факторима. Сама матрица је подвргнута тестовима значајности да би се проверила оправданост примене факторске анализе. Вредност индекса адекватности узорка износи 0.955 , што се иначе сматра одличним показатељем. Вредност Бартлетовог теста сферичности је такође висока и представља поуздану основу за примену факторске анализе (Табела 2).

Табела 2: Тестови статистичке значајности за димензију вредности

\begin{tabular}{|c|c|c|}
\hline \multicolumn{2}{|c|}{$\begin{array}{c}\text { Kaiser-Meyer-Olkin Measure of Sampling } \\
\text { Adequacy. }\end{array}$} & ,955 \\
\hline \multirow{2}{*}{$\begin{array}{c}\text { Bartlett's Test of } \\
\text { Sphericity }\end{array}$} & Approx. Chi-Square & 33563,706 \\
\cline { 2 - 3 } & Df & 1953 \\
\cline { 2 - 3 } & Sig. &, 000 \\
\hline
\end{tabular}

Као помоћни критеријум за одређивање броја издвојених фактора коришћен је Кателов scree тест (Табела 3), на коме се види да је у питању дванаест издвојених фактора, зато што до дванаестог фактора црвена линија има облик кривуље, која након тога постепено прелази у скоро праву линију.

Табела 3: Кателов scree тест

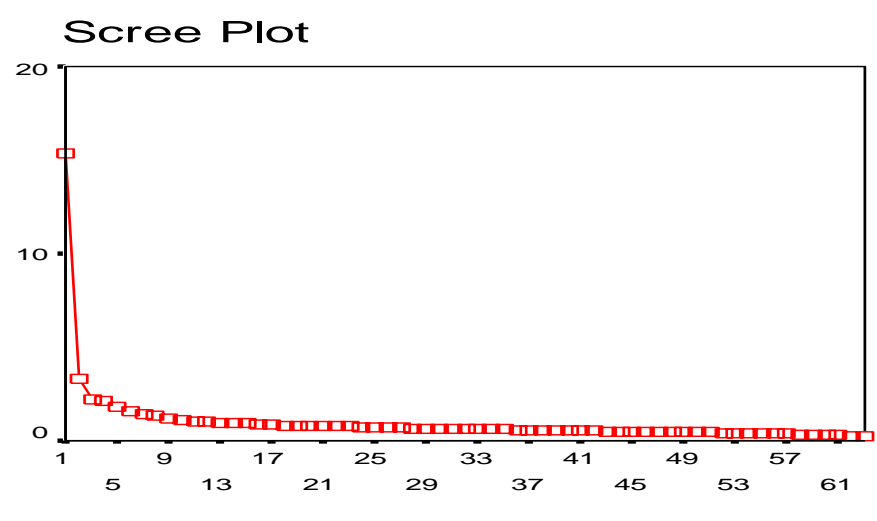

Component Number 
Полазни квантитативни показатељи у овој анализи добијени су из Скале процене „СВ-2011“, у којој су испитаници оцењивали важност понуђених вредности. Примењена факторска анализа је према назначеном критеријуму омогућила да се 63 манифестне варијабле, којима се описују вредности, редукују на 12 базичних (латентних) варијабли, односно фактора.

Издвојених (откривених) дванаест латентних варијабли - фактора (обухваћени су сви они фактори чија је вредност у тоталу већа од 1,00 ) у овом случају имају значење основних димензија пожељних вредности и покривају 53,176\% варијансе, што се може видети из Табеле 4.

Табела 4: Укупна варијанса

\begin{tabular}{|c|c|c|c|c|c|c|}
\hline \multirow[b]{2}{*}{ Component } & \multicolumn{3}{|c|}{ Initial Eigenvalues } & \multicolumn{3}{|c|}{ Rotation Sums of Squared Loadings } \\
\hline & Total & $\%$ of Variance & Cumulative \% & Total & $\%$ of Variance & Cumulative $\%$ \\
\hline 1 & 15,373 & 24,401 & 24,401 & 4,566 & 7,248 & 7,248 \\
\hline 2 & 3,320 & 5,270 & 29,671 & 3,921 & 6,224 & 13,472 \\
\hline 3 & 2,242 & 3,558 & 33,230 & 3,715 & 5,896 & 19,368 \\
\hline 4 & 2,094 & 3,323 & 36,553 & 3,367 & 5,345 & 24,713 \\
\hline 5 & 1,797 & 2,853 & 39,406 & 3,111 & 4,939 & 29,651 \\
\hline 6 & 1,569 & 2,491 & 41,897 & 2,924 & 4,642 & 34,293 \\
\hline 7 & 1,419 & 2,253 & 44,149 & 2,661 & 4,224 & 38,518 \\
\hline 8 & 1,346 & 2,137 & 46,286 & 2,520 & 3,999 & 42,517 \\
\hline 9 & 1,181 & 1,874 & 48,160 & 2,118 & 3,362 & 45,879 \\
\hline 10 & 1,131 & 1,795 & 49,955 & 1,751 & 2,780 & 48,659 \\
\hline 11 & 1,020 & 1,620 & 51,575 & 1,687 & 2,678 & 51,337 \\
\hline 12 & 1,008 & 1,601 & 53,176 & 1,158 & 1,838 & 53,176 \\
\hline 13 & ,955 & 1,517 & 54,692 & & & \\
\hline 14 & ,920 & 1,460 & 56,152 & & & \\
\hline 15 & ,914 & 1,451 & 57,603 & & & \\
\hline 16 & ,873 & 1,385 & 58,988 & & & \\
\hline 17 & ,853 & 1,355 & 60,343 & & & \\
\hline 18 & ,823 & 1,307 & 61,650 & & & \\
\hline 19 & ,814 & 1,293 & 62,942 & & & \\
\hline 20 & ,802 & 1,273 & 64,215 & & & \\
\hline 21 & ,781 & 1,240 & 65,455 & & & \\
\hline 22 & ,771 & 1,224 & 66,679 & & & \\
\hline 23 & ,748 & 1,188 & 67,867 & & & \\
\hline 24 & ,724 & 1,149 & 69,016 & & & \\
\hline 25 & ,716 & 1,137 & 70,153 & & & \\
\hline 26 & 698 & 1,109 & 71,262 & & & \\
\hline 27 & 679 & 1,077 & 72,339 & & & \\
\hline 28 & 657 & 1,043 & 73,382 & & & \\
\hline 29 & ,646 & 1,025 & 74,407 & & & \\
\hline 30 & ,640 & 1,015 & 75,422 & & & \\
\hline 31 & ,634 & 1,006 & 76,428 & & & \\
\hline
\end{tabular}




\begin{tabular}{|c|c|c|c|c|c|c|}
\hline \multirow[b]{2}{*}{ Component } & \multicolumn{3}{|c|}{ Initial Eigenvalues } & \multicolumn{3}{|c|}{ Rotation Sums of Squared Loadings } \\
\hline & Total & $\%$ of Variance & Cumulative $\%$ & Total & $\%$ of Variance & Cumulative $\%$ \\
\hline 32 & ,620 & ,984 & 77,412 & & & \\
\hline 33 & 608 & ,964 & 78,377 & & & \\
\hline 34 & ,603 & ,957 & 79,334 & & & \\
\hline 35 &, 591 & ,939 & 80,272 & & & \\
\hline 36 &, 587 & ,932 & 81,204 & & & \\
\hline 37 &, 577 & ,916 & 82,121 & & & \\
\hline 38 &, 569 & ,903 & 83,023 & & & \\
\hline 39 &, 560 & ,888 & 83,912 & & & \\
\hline 40 &, 547 & ,869 & 84,780 & & & \\
\hline 41 &, 529 & ,840 & 85,621 & & & \\
\hline 42 &, 518 & ,823 & 86,443 & & & \\
\hline 43 &, 511 & ,811 & 87,254 & & & \\
\hline 44 & ,499 & ,792 & 88,046 & & & \\
\hline 45 & ,493 & ,783 & 88,829 & & & \\
\hline 46 & ,488 & ,774 & 89,603 & & & \\
\hline 47 & ,481 & ,763 & 90,366 & & & \\
\hline 48 & ,461 & ,732 & 91,099 & & & \\
\hline 49 & ,458 & ,727 & 91,826 & & & \\
\hline 50 & ,447 & ,709 & 92,535 & & & \\
\hline 51 & ,443 & ,703 & 93,238 & & & \\
\hline 52 & ,430 & ,683 & 93,921 & & & \\
\hline 53 &, 425 & ,675 & 94,596 & & & \\
\hline 54 & ,417 & 661 & 95,257 & & & \\
\hline 55 &, 406 & ,645 & 95,902 & & & \\
\hline 56 & ,398 & ,632 & 96,535 & & & \\
\hline 57 & ,384 & ,610 & 97,144 & & & \\
\hline 58 & ,350 & ,555 & 97,700 & & & \\
\hline 59 &, 343 &, 544 & 98,244 & & & \\
\hline 60 & ,314 & ,499 & 98,743 & & & \\
\hline 61 & ,295 & ,468 & 99,211 & & & \\
\hline 62 & ,262 & ,416 & 99,628 & & & \\
\hline 63 & ,235 & ,372 & 100,000 & & & \\
\hline
\end{tabular}

Полазна основа за одређивање природе фактора јесте његова корелативна повезаност с манифестним варијаблама, што је приказано у варимакс ротираној матрици факторске структуре по Gutman-Kajser критеријуму (Табела 5). Вредности су наведене по истом редоследу као и у Скали процене „СВ-2011“. 
Табела 5: Ротирана матрица факторске структуре вредности

\begin{tabular}{|c|c|c|c|c|c|c|c|c|c|c|c|c|c|}
\hline \multirow{2}{*}{$\begin{array}{l}\text { P. } \\
\text { бр. }\end{array}$} & \multirow{2}{*}{$\begin{array}{c}\text { НАЗИВ } \\
\text { МАНИФЕСТНЕ } \\
\text { ВАРИЈАБЛЕ }\end{array}$} & \multicolumn{12}{|c|}{ ФАКТОРИ } \\
\hline & & $\phi 1$ & $\phi 2$ & $\phi 3$ & $\phi 4$ & $\phi 5$ & $\phi 6$ & $\phi 7$ & $\Phi 8$ & Ф9 & $\Phi 10$ & Ф11 & $\Phi 12$ \\
\hline 1. & ДОСТОЈАНСТВО & ,294 & ,020 & ,164 & ,210 & ,080 & ,096 & ,112 & 193 & ,273 & ,452 &,- 045 & 038 \\
\hline 2. & одлучност & 186 & ,230 & 098 & ,214 & ,176 & ,115 &,- 031 & ,129 & 293 & ,518 &,- 028 &,- 089 \\
\hline 3. & САВЕСНОСТ & ,282 & ,080 & ,038 & ,432 & ,158 & ,019 & ,079 &,- 021 & ,265 & ,355 &,- 043 &,- 059 \\
\hline 4 & ТОЛЕРАНТНОСТ & ,223 &, 457 & ,048 & ,083 &, 026 & ,145 & ,163 &,- 122 &, 009 & ,480 & ,033 & ,127 \\
\hline 5. & СЛОБОДА &,- 013 &,- 003 & 129 & 141 &, 042 & ,012 & ,193 & ,239 & ,021 &, 520 & ,337 & 083 \\
\hline 6. & $\begin{array}{l}\text { ПОСВЕТЕНОСТ } \\
\text { ПРОФЕСИЈИ }\end{array}$ &, 502 & ,080 & 093 & ,305 & ,142 &,- 010 & ,156 &,- 025 & ,260 & ,157 &,- 050 & ,001 \\
\hline 7. & СКРОМНОСТ & ,227 & ,442 & ,244 & ,325 & ,113 &, 027 & 032 &,- 042 &,- 055 & ,285 &,- 074 & ,061 \\
\hline 8. & СВЕТИ ПРЕЦИ & ,172 & ,115 & ,799 & ,187 & 133 & ,071 &,- 046 &, 034 & 046 & 079 &,- 009 &,- 008 \\
\hline 9. & ПОШТЕЊЕ &, 114 &, 039 & ,226 &, 577 &,- 031 &,- 161 & ,133 & ,189 & 082 & ,112 &, 065 & 029 \\
\hline 10. & MOT &, 066 &,- 054 & 075 &,- 020 &,- 011 & ,685 &,- 085 &, 041 & 012 & ,116 &,- 008 &,- 068 \\
\hline 11. & КОЛЕКТИВНИ ДУХ &, 421 &, 186 & 029 & ,486 & ,151 &, 057 &, 087 &, 024 & 067 &, 092 & ,116 &,- 070 \\
\hline 12. & АМБИЦИОЗНОСТ & ,191 &, 047 & 175 & 234 &,- 004 & ,290 & ,138 &, 044 &, 437 & ,115 &, 020 &,- 151 \\
\hline 13. & ПРИЈАТЕЉСТВО & ,177 &, 250 & 048 &, 548 & ,106 & ,087 & ,122 & ,106 & ,129 & 018 & , 171 &, 037 \\
\hline 14. & СВЕСТРАНОСТ &,- 038 & ,379 & 140 &, 300 & ,314 & ,195 &,- 083 &, 068 & 230 &, 184 &,- 064 &,- 147 \\
\hline 15. & СПАСЕЊЕ & ,121 & ,181 &, 802 & ,116 &, 027 & ,172 &, 036 &, 030 & ,026 &, 077 &,- 010 & ,038 \\
\hline 16. & \begin{tabular}{|l} 
ЧВРСТИНА \\
КАРАКТЕРА
\end{tabular} & ,105 & ,111 & 222 & ,458 & ,194 & ,110 &, 066 & ,243 & ,242 & ,150 & 019 & ,081 \\
\hline 17. & ЛИЧНИ УГЛЕД & ,204 & ,079 & 065 & 276 & ,006 & ,294 & ,077 & ,265 & 133 &,- 036 &,- 069 &, 460 \\
\hline 18. & МИР &, 058 &, 123 & 085 & 150 &, 044 &,- 046 & ,281 & ,178 &,- 070 & ,299 & ,166 &, 463 \\
\hline 19. & ХЛАДНОКРВНОСТ & ,253 &, 038 &,- 035 & 275 & ,316 &, 067 &,- 066 & ,245 & 133 & 180 &,- 041 &,- 150 \\
\hline 20. & ДРУЖЕЉУБИВОСТ & ,186 &, 223 & 109 &, 590 &, 061 &, 183 & 135 &, 087 &,- 039 & , 100 &, 056 &, 051 \\
\hline 21. & ХЕДОНИЗАМ &,- 027 &, 061 &, 110 & ,149 &, 062 & ,656 &, 046 &, 043 &,- 103 &, 001 &,- 015 &, 042 \\
\hline 22. & ПОНОС & ,106 & ,087 & 081 & 150 & ,121 & ,411 &,- 039 & ,519 & ,072 & ,110 & ,068 & 070 \\
\hline 23. & МУДРОСТ &, 046 & ,339 &, 096 & 254 & ,228 &, 010 &,- 123 & ,333 & ,360 &, 035 &, 037 &, 075 \\
\hline 24. & ИСТИНОљУБИВОСТ & ,190 & ,283 & ,104 &, 410 & ,168 &,- 106 & 023 & ,393 &, 020 & ,028 &,- 066 & 130 \\
\hline 25. & ЧАСТ & ,177 & ,160 & ,131 & 215 &, 081 &, 033 &, 050 & ,608 & ,119 &, 067 & ,083 &, 059 \\
\hline 26. & МИСИОНАРСТВО & ,181 &, 175 &, 263 &, 012 &,- 034 & ,311 &, 230 & ,201 &, 045 &, 150 &,- 168 &,- 227 \\
\hline 27. & ЦРКВА & ,117 & ,089 & ,843 &, 060 &, 011 & ,110 & 070 &, 063 &, 060 &, 042 & 017 & 044 \\
\hline 28. & ОБУЧЕНОСТ & ,408 & ,016 & 041 & 089 & ,108 &,- 058 & ,118 & ,127 &, 565 &, 067 & ,085 & 011 \\
\hline 29. & ПОЖРТВОВАНОСТ & ,678 & ,209 & 104 &, 023 &, 004 &, 087 & ,102 & ,202 &, 030 &, 096 &,- 043 &,- 054 \\
\hline 30. & САМОПОШТОВАЊЕ &, 140 & ,333 &, 053 &, 007 & ,097 &, 216 &, 124 & ,492 & ,194 &, 120 &,- 027 &,- 054 \\
\hline 31. & ЉУДСКА ПРАВА & ,120 & ,350 &, 072 &,- 011 & ,076 & ,011 & ,428 & 298 & 186 & ,185 & 093 & ,192 \\
\hline 32. & НАДА & ,128 & ,429 &, 167 & ,103 & ,167 & ,085 & ,130 & ,124 & ,207 &, 023 &, 084 &, 057 \\
\hline 33. & АВАНТУРИЗАМ & ,037 & ,168 & 109 & 084 &,- 188 &, 511 & ,173 & ,156 & ,138 & $\begin{array}{c}- \\
2,395 \\
\text { E-05 } \\
\end{array}$ &,- 051 &,- 401 \\
\hline 34. & НОВАЦ &,- 052 &,- 040 &, 050 &,- 081 & ,136 &, 565 &,- 099 &,- 021 &, 267 &,- 073 & , 185 & ,203 \\
\hline 35. & ЗНАЊЕ & ,173 &, 263 &, 064 &, 076 & ,078 & ,055 & ,081 & 135 & 648 & 113 & 144 &,- 019 \\
\hline 36. & ОДАНОСТ & ,649 & ,185 & ,117 & ,191 &, 077 &, 057 &, 050 &, 045 & ,179 & ,125 &, 034 &, 033 \\
\hline 37. & БОГ & ,094 & ,132 & ,822 & 033 &,- 004 & ,108 & ,035 & ,096 & 083 & ,051 & 076 &,- 008 \\
\hline 38. & ВEРНОСТ & ,738 &, 083 &, 215 &, 077 & ,138 &,- 001 &, 029 & ,173 &, 040 &, 066 & ,085 &,- 052 \\
\hline
\end{tabular}




\begin{tabular}{|c|c|c|c|c|c|c|c|c|c|c|c|c|c|}
\hline \multirow{2}{*}{$\begin{array}{l}\text { P. } \\
\text { бр. }\end{array}$} & \multirow{2}{*}{$\begin{array}{c}\text { НАЗИВ } \\
\text { МАНИФЕСТНЕ } \\
\text { ВАРИЈАБЛЕ }\end{array}$} & \multicolumn{12}{|c|}{ ФАКТОРИ } \\
\hline & & $\phi 1$ & $\phi 2$ & $\phi 3$ & $\phi 4$ & $\phi 5$ & $\phi 6$ & $\phi 7$ & $\Phi 8$ & $\Phi 9$ & $\Phi 10$ & $\Phi 11$ & $\Phi 12$ \\
\hline & ОТАЏБИНИ & & & & & & & & & & & & \\
\hline 39. & ПРАВДОЉУБИВОСТ & 304 & 302 & 089 & 248 & 232 &,- 109 & 162 & ,330 & ,070 & ,051 & 131 &,- 058 \\
\hline 40. & ПослУШНОст &, 505 & 207 & 168 & 109 &,- 090 & ,307 & 199 &,- 049 & ,066 &,- 051 &,- 049 & 161 \\
\hline 41. & СОЛИДАРНОСТ & ,474 & ,371 & 059 & 172 & 142 & ,037 & , 127 & 137 &,- 090 & 132 & 117 & 001 \\
\hline 42. & ПОПУЛАРНОСТ & ,092 & ,119 & ,069 &,- 049 &,- 016 & ,687 & ,111 & ,014 & ,011 & ,016 & -037 &,- 017 \\
\hline 43. & ЉУБАВ & 132 & ,556 & ,172 & ,191 &,- 014 & ,157 & ,115 & ,041 & ,067 & 013 & 176 & 070 \\
\hline 44. & УМЕРЕНОСТ & 128 & 640 & ,001 & ,122 & ,162 &,- 005 & ,112 & , 141 & ,186 &, 065 & 080 &,- 071 \\
\hline 45 . & МИЛОСРЪЕ & 181 & 646 & ,216 &, 028 & ,136 & ,038 & 139 & ,138 & ,017 & ,041 &,- 017 & ,011 \\
\hline 46. & ДИСЦИПЛИНОВАНОСТ &, 562 & 149 & 050 & 215 & 127 & ,047 & 139 & ,053 & ,303 &,- 022 & ,020 & 100 \\
\hline 47. & ТРАДИЦИЈА & 285 & 237 & ,431 & ,163 & 153 & 008 & 037 & ,256 & 051 &,- 005 & 065 &,- 156 \\
\hline 48. & ДАРЕЖЉИВОСТ & 180 & ,494 & , 197 & 197 - & 184 & ,056 & 155 & ,295 &,- 046 &,- 008 & ,027 &,- 176 \\
\hline 49. & ХРАБРОСТ & 310 & ,123 & 081 & 214 & ,024 & 215 & ,091 & ,226 & , 197 & ,047 & ,176 &,- 342 \\
\hline 50. & ДЕМОКРАТИЈА & 134 & ,147 & ,081 &,- 001 & ,211 & 082 & ,452 & ,244 &,- 037 & 079 &,- 101 &,- 002 \\
\hline 51. & ЧОВЕЧНОСТ & 149 & ,380 & ,155 & 204 & 180 &,- 063 & 300 & ,226 & ,061 &,- 003 & 212 &,- 020 \\
\hline 52. & ПОРОДИЦА & 018 & 076 &, 072 &, 234 &, 041 & 032 & 018 &,- 021 &, 082 &,- 019 & 669 &,- 016 \\
\hline 53. & \begin{tabular}{|l|} 
БЕЗБЕДНОСТ \\
РЕПУБЛИКЕ СРБИЈЕ \\
\end{tabular} & ,576 & ,004 & ,175 & 080 & 316 &,- 016 & ,149 & ,111 & ,079 & ,034 & 239 & ,041 \\
\hline 54. & ПОШТОВАЊЕ & ,172 & ,273 & ,122 & ,280 & 187 &,- 015 & 251 & ,211 & ,157 & ,047 & ,253 & ,030 \\
\hline 55. & НЕЗАВИСНОСТ & 159 & ,081 & ,112 & 029 & ,447 &,- 066 & ,176 & ,285 &,- 047 & ,272 & 210 &,- 157 \\
\hline 56. & ЗДРАВЉЕ & 121 &, 124 &,- 050 &,- 089 & ,120 &,- 019 &,- 060 & ,068 &, 051 & 096 & 695 & 031 \\
\hline 57. & $\begin{array}{l}\text { РАВНОПРАВНОСТ } \\
\text { ПОЛОВА }\end{array}$ & 129 & ,122 &,- 027 & ,098 & 119 & ,053 & ,659 &,- 041 & ,112 & ,074 &,- 065 &,- 043 \\
\hline 58. & ЈЕДНАКОСТ & 094 & ,002 & ,050 & 284 & ,375 &,- 063 & ,467 &,- 024 & ,050 & ,002 & ,188 & 012 \\
\hline 59. & \begin{tabular}{|l|} 
НАЦИОНАЛНА \\
РАВНОПРАВНОСТ \\
\end{tabular} & 158 & ,171 & ,010 & ,141 & ,266 & 049 & ,677 &,- 012 & ,047 & ,033 & ,014 & ,063 \\
\hline 60. & СОЦИЈАЛНА ПРАВДА & 114 &, 165 & 070 & 091 &, 592 & 007 & 443 & ,034 & 028 & 094 & 099 &, 040 \\
\hline 61. & \begin{tabular}{|l|} 
НЕПОВРЕДИВОСТ \\
ВЛАСНИШТВА \\
\end{tabular} & ,053 & , 124 &,- 009 & 094 & ,705 & ,086 & , 158 & ,172 & ,064 & 009 & ,044 & ,038 \\
\hline 62. & \begin{tabular}{|l|} 
ОЧУВАҢЕ ПРИРОДЕ \\
И ЧОВЕКОВЕ \\
ОКОЛИНЕ \\
\end{tabular} & 184 & ,212 & ,174 & 165 & ,492 & 042 & 172 &,- 011 & ,155 &,- 058 &, 127 & ,036 \\
\hline 63. & ВЛАДАВИНА ПРАВА & 147 & 156 & ,008 & 022 &, 727 &,- 028 & 159 &, 043 &, 055 &, 080 &,- 003 & 048 \\
\hline
\end{tabular}

Први издвојени фактор (Табела 6) има највећи утицај на укупну варијансу $(24,401 \%)$ и репрезентује манифестне варијабле, које се односе на кардиналне војне вредности. Из прве колоне Табеле 5 ротиране матрице факторске структуре смо издвојили следеће вредности: $(1 / 38 / 0,738)^{9}$ верност отацбини; (2/29/0,678) пожртвованост; (3/36/0,649) оданост; $(4 / 53 / 0,576)$ безбедност Републике Србије (5/46/0,562) дисциплинованост; (6/40/0,505) послушност; (7/6/0,502) посвећеност професији; (8/41/0,474) солидарност; и $(9 / 49 / 0,310)$ храброст.

9 Први број представља редни број варијабле по значају у датом издвојеном фактору, други означава редни број варијабле у коришћеној Скали процене „СВ-2011“, трећи број је коефицијент повезаности варијабле са фактором. 
Табела 6: Први издвојени фактор кардиналне војне вредности

\begin{tabular}{|c|c|c|c|}
\hline $\begin{array}{l}\text { Редни број } \\
\text { варијабле } \\
\text { по значају }\end{array}$ & $\begin{array}{c}\text { Редни } \\
\text { број } \\
\text { варијабле } \\
\text { у } \\
\text { упитнику }\end{array}$ & НАЗИВ ВАРИЈАБЛЕ & $\begin{array}{c}\text { Коефицијент } \\
\text { повезаности } \\
\text { варијабле } \\
\text { са фактором }\end{array}$ \\
\hline 1. & 38 & $\begin{array}{c}\text { ВЕРНОСТ ОТАЏБИНИ (љубав, брига за } \\
\text { отаџбину и спремност да се жртвујемо } \\
\text { за њу) } \\
\end{array}$ & 0.738 \\
\hline 2. & 29 & $\begin{array}{c}\text { ПОЖРТВОВАНОСТ (спремност на } \\
\text { одрицања ради добробити своје } \\
\text { јединице, ВС и отаџбине без очекивања } \\
\text { награде) }\end{array}$ & 0.678 \\
\hline 3. & 36 & $\begin{array}{c}\text { ОДАНОСТ (приврженост својој } \\
\text { јединици и свим њеним } \\
\text { припадницима) } \\
\end{array}$ & 0.649 \\
\hline 4. & 53 & $\begin{array}{c}\text { БЕЗБЕДНОСТ РЕПУБЛИКЕ СРБИЈЕ } \\
\text { (одсуство физичког и духовног } \\
\text { угрожавања основних вредности } \\
\text { грађана Републике Србије и њихових } \\
\text { добара) }\end{array}$ & 0.576 \\
\hline 5. & 46 & $\begin{array}{c}\text { ДИСЦИПЛИНОВАНОСТ (савесно } \\
\text { извршавање наређења } \\
\text { претпостављеног и поштовање прописа } \\
\text { и закона) } \\
\end{array}$ & 0.562 \\
\hline 6. & 40 & ПОСЛУШНОСТ (покорност, кротост) & 0.505 \\
\hline 7. & 6 & $\begin{array}{c}\text { ПОСВЕЋЕНОСТ ПРОФЕСИЈИ (стручно, } \\
\text { савесно и одговорно обављање својих } \\
\text { послова и задатака) }\end{array}$ & 0.502 \\
\hline 8. & 41 & $\begin{array}{c}\text { СОЛИДАРНОСТ (свест о потреби } \\
\text { узајамне одговорности и настојање да } \\
\text { се лични интереси подреде интересима } \\
\text { своје јединице) } \\
\end{array}$ & 0.474 \\
\hline 9. & 49 & $\begin{array}{c}\text { ХРАБРОСТ (спремност да се човек суочи } \\
\text { са страхом, неизвесношћу и опасношћу } \\
\text { без обзира на ризик) }\end{array}$ & 0.310 \\
\hline
\end{tabular}

На основу Табеле 6 јасно уочавамо да је код првог фактора названог кардиналне војне вредности издвојено девет варијабли, где првих седам има висок коефицијент повезаности варијабле са фактором и да су то управо оне вредности које је неопходно да буду високо рангиране код сваког професионалног војног лица. Наведене вредности представљају неопходан и довољан услов успешне реализације предвиђених мисија и задатака Војске Србије. Будући да први издвојени фактор покрива четвртину укупне варијансе $(24,401 \%)$, може се закључити да су професионална војна лица ВС високо свесна важности наведених вредности. 


\section{ЕВАЛУАЦИЈА ВРЕДНОСТИ КОДЕКСА ЧАСТИ}

Овим истраживањем извршена је и евалуација Кодекса части професионалних припадника Војске Србије, којим је установљено следећих десет основних вредности: верност отацбини, посвећеност професији, оданост, храброст, дисциплинованост, солидарност, човечност, достојанство, пожртвованост и поштовање. Упоређујући први фактор кардиналне војне вредности, којим је обухваћено девет манифестних варијабли (вредности): верност отацбини, пожртвованост, оданост, безбедност Републике Србије, дисциплинованост, послушност, посвећеност професији, солидарност и храброст, са Кодексом части, види се да безбедност Републике Србије и послушност нису заступљене у Кодексу части, док човечност, достојанство и поштовање нису заступљене у фактору кардиналне војне вредности. Ако се узме у обзир да постоји велика сличност између послушности и оданости као и између безбедности Републике Србије и верности отацбини, закључујемо да се поклапају вредности из Кодекса части припадника Војске Србије и првог фактора кардиналне војне вредности и да би војни етос требало изграђивати на вредностима предвиђеним Кодексом части. Набројане вредности су у функцији безбедности Републике Србије. Ако би професионална војна лица Војске Србије извршила интериоризацију безбедности Републике Србије као кардиналне војне вредности, онда би таква Војска својом унутрашњом снагом била гарант успешног извршења предвиђених мисија и задатака.

\section{БИБЛИОГРАФИЈА}

1. Allport, Vernon, Lindzey.; Study of Values, Houghton Mifflin, Boston, 1960.

2. Bilsky, W., Schwartz, H. S.; Values and Personality, European Journal of Personality, 1994.

3. Вујачић, В.; Област вриједности, Универзитетска реч, Титоград 1984.

4. Гроздић, Б.; Православље и рат, Новинско издавачки центар „Војска“, Београд 2001.

5. Карапанџин, С.; Кодекс части припадника Војске Србије, Нови гласник, Београд 2012, 125.

6. Мужић, В.; Методологија педагошког истраживања, Завод за издавање уџбеника, Сарајево 1973, 318.Маринковић, Д.; О заштити обицирске војничке части, Свеславенска књижара Стефановић, Београд 1932, 10.

7. Шушњић Ђ.; Религија I, Чигоја, Београд 1998, 215-222.

\section{STRATEGIC APPROACH TO EVALUATION OF CODE OF HONOR OF THE SERBIAN ARMY}

The Code of Honor of the Army of Serbia shall be governed by general moral principles of the military profession, its core values and standards of conduct of members of the Army of Serbia that their behavior aligns with the provisions of the Code of Honor. We 
started the research with the assumption that the values determined correctly are provided by the Code of Honor, taking into account that the values are the guiding principles of our life decisions. The research was realized on a representative sample of 1477 respondents professional members of the Army of Serbia using assessment scales Likert author of the article "SV-2011" which includes 63 values. Respondents were asked to rate how important the values offered to them were and to circle a number on the answer sheet describing the answer they agreed with. Applying the factor analysis, we came to the conclusion that the most important factor called cardinal military values was singled out, which contains nine out of ten values provided by the Code of Honor. In this way, we evaluated the given values and came to the knowledge that they were correctly determined by the Working Team for the development of the Code of Honor. The survey results we can not with certainty lead to the conclusion that there was an acceptance of those values, because it is a short period of time from the moment of the adoption of the Code of Honor to the realization of research.

Keywords: values, Code of Honor, cardinal military values, factor analysis 